\title{
AN ECONOMETRIC ANALYSIS OF IMPACTS OF EXCHANGE RATES ON IMPORTS: AN EMPIRICAL STUDY ON SRI LANKAN CONTEXT
}

\author{
S. Nisthar ${ }^{1}$ \& A. M. M. Mustafa ${ }^{2}$ \\ amustafa@seu.ac.lk \\ ${ }^{1}$ Dept. of Local Government, Eastern Province, Trincomalee \\ ${ }^{2}$ Senior Lecturer in Business Economics, Faculty of Management and Commerce, \\ South Eastern University of Sri Lanka, Oluvil, Sri Lanka
}

\begin{abstract}
This study aims to find out the relationship between the trends of various exchange rates and the trend of imports on Sri Lankan empirical context. The quantitative method is used by using the time series data in this study. The annual time series data used in this study are collected from the annual report of Central Bank of Sri Lanka for the time periods from year 1950 to year 2017. The multiple regression model is used to find out the impact of the independent variables such as Indian Rupees, Japanese Yen, Pound Sterling, and US Dollar on the dependent variable such as imports of Sri Lanka. The Granger Causality Test is used to find out the causal relationship among all the variables. The Johansen Co-Integration Test is used to find out long run equilibrium relationship among the variables. Pound Sterling of United Kingdom and Dollar of United Statesare positively impacts on the Imports of Sri Lanka. Indian Rupees and Japanese Yen are inversely associated with the imports. According to the Granger Causality Test, one way causal relationship is found between the currencies such as Indian Rupees, Japanese Yen, Pound Sterling, and US Dollar and the imports. The results of Johansen Co-integration Test vividly ensure the long run equilibrium relationship of the variables and the movement of all the variables together in the long run equilibrium. Paradox is recommended to be named as Import Paradox of PoundDollar. The structural breakpoint is found in year 2009 which is the year of cease-fire in Sri Lanka.
\end{abstract}

Keywords: exchange rates, imports, multiple regression, granger cause, johansen cointegration 


\section{Introduction}

The currency depreciation and appreciation of the domestic countries all over the world are seriously perceived by the respective governments and the persons connected with the international business in terms of their domestic products, exports, imports, and so on. The appreciation in exchange rate of a country in the floating exchange rate system decreases the currency value of a domestic country and also increases the currency value of the domestic country.

The exchange rate of the currency occupies a portfolio that holds the bulk of its investments, which determine the portfolio are real return. As supply and demand for currencies change, the values of those currencies change. When the US Dollaris strong, imports seem less expensive, leading to increased demand for imported products and the currency needed to purchase them. In addition, when interest rates in another nation are higher than those in the U.S., demand for the foreign currency rises, as people buy the currency in order to invest in the other nation's securities. A declining exchange rate obviously decreases the purchasing power of income and capital gains derived from any returns. Therefore, a trade deficit develops as the result of a strong dollar. The opposite effects result from a weak U.S. dollar. While importers prefer a strong dollar, exporters prefer a weak dollar.

Moreover, the exchange rate influences other income factors such as interest rates, inflation and even capital gains from domestic securities. While exchange rates are determined by numerous complex factors that often leave even the most experienced economists flummoxed, investors should still have some understanding of how currency values and exchange rates play an important role in the rate of return on their investments. Therefore, the effects of currency crises in other nations are not limited to those nations. They can affect our economy and our lives in important ways.

The objective of this study is to find out the association-ship between the changes in the various exchange rates of the currencies in terms of the value of Sri Lankan currency and the rupees values of imports of Sri Lanka. In the arena of international trade in the context of Sri Lanka, the trade balance of Balance of Payment is influenced by the variations in the value of exchange rate of the respective currencies in terms of the value of Sri Lankan currency. As a result, it is significant to find out the relationship between the changes in the value of foreign currencies in terms of Sri Lankan currency value. Therefore, in this study, it is significantly perceived if there is a relationship between the trends of various exchange rates and the trend of imports on Sri Lankan 
empirical context. In addition, the null hypothesis of "there is no relationship between the values of the different foreign currencies and the value of Sri Lankan currency value" is directly derived from the objective of this study.

\section{Objective of the Study}

To find out the relationship between the trends of various exchange rates and the trend of imports on Sri Lankan empirical context.

\section{Literature Review:}

Ionel, Carmen, and Bogdan (2018) aimed to assess the function of exchange rate influencing on international competitiveness in imports and export in the context of Romania and to find out the relationship between them by using regression model. They found out form this study that the currency exchange rate weakened the nature of the imports in the context of Romania and those two variables were inversely related. The presence of the deprecation of currency in the country decreased the competitiveness of the products produced in the foreign countries along with the negative influence on the imports.

Faheem, Irfan, and Muhammad (2017) examined the gap and the relationship of the parameters such as exchange rates, imports, and exports of Pakistan by using linear regression model with the help of statistical software, SPSS 18. They found and concluded that many economies all over the world faced the problem of fluctuations in the currency exchange rates. The fluctuations in the exchange rate are directly and significantly connected with imports of Pakistan.

Policies must be made in a way that economy of Pakistan may proceed towards growth. Secondary annual data was collected from Pakistan Bureau of Statistics Government of Pakistan and World Bank from the year 1985-2015. For data analysis, SPSS 18 was used by using linear regression to examine the relationship between the variables. The study concluded that exchange rate fluctuation significantly and positively related to export and import of Pakistan.

Hassana and Nufile (2016) aimed to examine the relationship between the exchange rate and the value of exports and imports in the context of Sri Lanka after the open economic policy using the time series data from 1980 to 2014. They found that there was a positive relationship between the exchange rate and exports and imports. And also the relationship between the exchange rate and the value of exports and imports in 
Sri Lanka was significant after the open economic policy regime which was implemented in Sri Lanka after year 1977.

Khaled (2016) studied to find out the ways of influencing of the exchange rate on the import and export of a country by using descriptive analysis via the secondary sources. He found that the fluctuations of currency value of the countries of G7 affected their exports and imports values during 1982 to 1997. Further, the exchange rates of a country affected inflation, the gains from capital, and the interest rates in the respective countries. And also, as the value of US Dollar is higher, the purchasing power of the currency of US is higher in the international arena. As a result, more goods and services are attracted to be purchased by USA from the foreign countries. The imports can be increased and the currency needed to purchase the goods and services is relatively less than earlier.

Ali and Usman (2005) aimed to analyze the relationship between imports, exports, and real exchange rate in Pakistan by using quantitative analysis. They found that there was a direct relationship between the real exchange rate and imports. Further, real exchange rate caused sudden shock on the imports.

Cathy (2009) aimed to review the relationship between the changes in the import prices and the changes in the currency value of US dollar using the time series data for the time period of 1999 - 2008 in USA. He found that the changes in exchange rate affected the prices of imports in US. Deprecation in exchange rate of US increased the cost of imports and the appreciation of US Dollar decreased the cost of imports.

Mary, Oleg, and Jozef (2013) analyzed to find the relationship between the share of imports and the exchange rate in Belgium using the data collected for the period of 2000 to 2008 . They found that the decrease in the exchange rate led to increase the high share of import and the high share of market.

\section{Methodology}

The quantitative method is used by using the time series data in this study. The annual time series data used in this study are collected from the annual report of Central Bank of Sri Lanka for the time periods from year 1950 to year 2017. Thus, the sample used in this study is 68 years. The tools used in this study so as to achieve the objective of this study are the Multiple Regression, Granger Causality Test, and Johansen Cointegration Test. Based on the objective of this study, the following functions are constructed and estimated. 


$$
\begin{aligned}
& \operatorname{IMP}=F(\operatorname{INR}, J A Y, S T P, U S D) \ldots \ldots \ldots \ldots \ldots \ldots \ldots \ldots \ldots \ldots \ldots \\
& \operatorname{In}\left(I M P_{t}\right) \\
& \varepsilon_{t} \ldots \ldots(2)
\end{aligned}
$$

Where:

$$
\begin{aligned}
& I M P_{t} \text {-Imports } \\
& \text { INR } R_{t}-\text { Indian Rupees } \\
& \text { JAY }- \text { Japanese Yen } \\
& \text { STP } P_{t}-\text { Pound Sterling } \\
& U S D_{t}-\text { USDollar } \\
& \phi_{1}, \phi_{2}, \phi_{3}, \phi_{4}, \phi_{5}-\text { Coefficients } \\
& \varepsilon_{t}-\text { Error Term } \\
& \text { In-Natural Logarithm }
\end{aligned}
$$

The above multiple regression model is used to find out the relationship between the independent variables such as Indian Rupees, Japanese Yen, Pound Sterling, and US Dollar and the dependent variable such as imports of Sri Lanka. The Granger Causality Test is used to find out the causal relationship among all the variables. The Johansen Co-Integration Test is used to find out long run equilibrium relationship among the variables.

The Chow Breakpoint Test is used to find out the structural break in the data sets of time series used in this study from 1950 - 2017. After finding the structural break in the data set, the original multiple regression model is estimated as follows:

$$
\begin{aligned}
& \operatorname{In}\left(I M P_{t}\right)=\phi_{1}+\phi_{2} * \operatorname{In}\left(I N R_{t}\right)+\phi_{3} * \operatorname{In}\left(J A Y_{t}\right)+\phi_{4} \operatorname{In}\left(S T P_{t}\right)+\phi_{5} * \operatorname{In}\left(U S D_{t}\right)+ \\
& D U+\varepsilon_{t} \ldots \ldots \text { (3) }
\end{aligned}
$$

In equation (3), a new independent variable such as DU is added. DU is the dummy variable used to separate the structural point found in the particular year by using zero and one. Before the absence of the structure break in the trend of data set of time series, the binary of zero (o) is used and after the presence of the structural break in the data set of time series, the binary number of one (1) is used to compare the changes occurred in the two time periods. 
In this study, four currencies such as Indian Rupee, Japan Yen, Pound Sterling, and US Dollar are used in the model to find the respective relationship as these currencies are popular in Sri Lanka international transactions and thereby the annual time series data on these currencies are available for the time period selected in this model.

\section{Data Presentation and Analysis}

To achieve the objective of this study, the results of Multiple Regression model, Granger Causality Test, and Johansen Co-Integration Test are presented and analyzed in this part.

\section{Multiple Regression:}

Table 01 shows the results of Multiple Regression model used in this study. In this multiple regression model, LOG(IMP) - Import of Sri Lanka is the dependent variable. LOG(INR) - the values of Indian currency (Rupees), LOG(JAY) - the values of Japan currency (Yen), LOG(STP) - the values of United Kingdom currency (Pound Sterling), LOG(USD) - the values of United States currency (US Dollar) are used as the dependent variables in the model.

\section{Table 01: Results of Multiple Regression}

\begin{tabular}{|c|r|r|r|r|}
\hline Variable & \multicolumn{1}{|c|}{ Coefficient } & Std. Error & \multicolumn{1}{c|}{ t-Statistic } & \multicolumn{1}{l|}{ Prob. } \\
\hline C & 2.535759 & 1.092159 & 2.321786 & 0.0235 \\
\hline LOG(INR) & -0.103555 & 0.130062 & -0.796193 & 0.4289 \\
\hline LOG(JAY) & -0.169709 & 0.164828 & -1.029611 & 0.3071 \\
\hline LOG(STP) & 0.312980 & 0.216785 & 1.443735 & 0.1538 \\
\hline LOG(USD) & 1.128220 & 0.350734 & 3.216738 & 0.0020 \\
\hline R-squared & 0.979236 & \multicolumn{2}{|c|}{ Mean dependent var } & 7.525980 \\
\hline
\end{tabular}

According to the results of the multiple regression model (Table 01), the estimated model of this study is as follows:

$$
\operatorname{lnIMP}=2.53-0.10 \ln \mathrm{INR}-0.16 \ln \mathrm{JAY}+0.3 \ln \mathrm{STP}+1.12 \ln \mathrm{USD}
$$

As per the above estimated multiple regression model (4), the currencies such as Indian Rupees and Japanese Yen are inversely associated with the imports over the empirical time period of 66 years in the Sri Lankan context. The independent variables 
such as Pound Sterling of United Kingdom and Dollar of United States of America are directly connected with the independent variable known as Imports of Sri Lanka. Further, the increase of one percent in Indian Rupees leads to decrease in imports of Sri Lanka by 0.10 percent. And also, the increase of one percent in Japanese Yen causes to decrease the imports of Sri Lanka by 0.16 percent whereas the increase of one percent in Pound Sterling makes the imports of Sri Lanka to be also increased by 0.3 percent. Similarly, the increase of one percent in US Dollar results in the increase of 1.12 percent in imports.

In the above estimated model, the currency of US Dollar of United States of America is statistically significant as the value of probability is 0.0020 which is less than $5 \%$. Thus, at less than five percent significant level, the alternative hypothesis of "there is a significant relationship between the imports of Sri Lanka and the currency of US Dollar" can't be rejected but can be statistically and significantly confirmed.

The most influencing variable of this entire model of this study, which is affecting the value of imports of Sri Lanka, is the currency of Dollar of United States of America as the increase of one percent in US Dollar results in the increase of 1.12 percent of imports of Sri Lanka. The least influencing independent variable is the currency of Indian Rupees which is affecting the independent variable of imports of Sri Lanka. And also, the value of $\mathrm{R} 2$ is around 0.98 which is representing the percentage of 98 . It vividly denotes that all the four independent variables such as INR, JAY, STP, and USD used in the multiple regression model are collectively affecting the dependent variable of imports by 98 percent.

That is, the percentage of the variance explained by all the four independent variables on the dependent variable of imports is 98 percent. Thus, the factors or the independent variables used within this multiple regression model are mostly influencing the effect on imports that is the dependent variables in this model. Therefore, only 0.2 percent is the external factors or the variables which are influencing the impacts on imports of Sri Lanka. Thus, the error tem of this model is highly minimized as there is no need to add some more relevant independent variables in this model.

\section{Granger Causality Test}

Table 02 shows the results of granger causality test of the multiple regression model used in this study. The value of lag is very significant while testing the test of Granger Causality. While the value of lag is becoming higher, the probability of rejecting null hypothesis is also becoming higher and vice versa. Accordingly, the maximum value 
of lag used in this Granger Causality test is 02 . Therefore, the number of observations also decreases while the number of lag increases. The null hypothesis of "LOG(INR) does not Granger Cause LOG(IMP)" is rejected as the value of probability of this causational relationship is less than 5 percent $(\mathrm{p}=0.0494 / \mathrm{p}<0.5 \%)$.

According to the confirmed nature of the alternative hypothesis of "LOG(INR) does Granger Cause LOG(IMP)", the currency of Indian Rupees causes the value of imports of Sri Lanka. The null hypothesis of "LOG(JAY) does not Granger Cause LOG(IMP)" is rejected as the value of probability of this causational relationship is less than 5 percent $(\mathrm{p}=0.0047 / \mathrm{p}<0.5 \%)$.

\section{Table 02: Results of Granger Causality Test}

\begin{tabular}{|l|c|c|}
\hline \multicolumn{1}{|c|}{ Null Hypothesis: } & $\begin{array}{c}\text { F- } \\
\text { Statistic }\end{array}$ & Prob. \\
\hline LOG(INR) does not Granger Cause LOG(IMP) & 3.16208 & 0.0494 \\
\hline LOG(JAY) does not Granger Cause LOG(IMP) & 5.85579 & 0.0047 \\
\hline LOG(STP) does not Granger Cause LOG(IMP) & 3.50961 & 0.0361 \\
\hline LOG(USD) does not Granger Cause LOG(IMP) & 7.17417 & 0.0016 \\
\hline
\end{tabular}

Accordingly, the alternative hypothesis of "LOG(JAY) does Granger Cause LOG(IMP)" is confirmed. Thus, the currency such as Japanese Yen causes the imports of Sri Lanka. Further, the null hypothesis of "LOG(STP) does not Granger Cause LOG(IMP)" is rejected as the corresponding value of probability of F-Statistic is less than 5 percent $(\mathrm{p}=0.0361 / \mathrm{p}<0.5 \%)$. Thus, the alternative hypothesis of "LOG(STP) does Granger Cause LOG(IMP)" is accepted. Therefore, in this causational nature between the variables used in the multiple regression model, the currency of Pound Sterling of United Kingdom causes the imports of Sri Lanka. Similarly, the null hypothesis of "LOG(USD) does not Granger Cause LOG(IMP)" is rejected at less than five percent significant level as the corresponding value of probability of FStatistic is less than 5 percent $(\mathrm{p}=0.0016 / \mathrm{p}<0.5 \%$ ). In this nature of rejecting null hypothesis, the alternative hypothesis of "LOG(USD) does Granger Cause LOG(IMP)" is statistically and significantly confirmed. Thus, there is a causational relationship between the currency of US Dollar and the value of imports. That is, US Dollar causes the imports of Sri Lanka.

Finally, there is a one way causal relationship between the currencies such as Indian Rupees, Japanese Yen, Pound Sterling, and US Dollar and the imports of Sri Lanka. 


\section{Johansen Co-integration Test}

Table 03 indicates the results of the Johansen Co-integration test (Trace Test) of the variables used in the multiple regression model used in this study. Further, this test is used to find out the long run relationship between the variables used in the multiple regression model. In this test, the value of Trace Statistic, Critical Value, and Probability value are considered to find the decisions of the long run equilibrium relationship between the variables. According to the Johansen Co-integration Trace Test, there are maximum one co-integrating equation (long run equilibrium equations) at 5 percent significant level $(\mathrm{p}=0.000 / \mathrm{p}<5 \%)$.

\section{Table 03: Johansen Co-integration: Trace Test}

\begin{tabular}{|c|c|c|c|c|}
\hline $\begin{array}{c}\text { Hypothesized } \\
\text { No. of CE(s) }\end{array}$ & Eigen -value & $\begin{array}{c}\text { Trace } \\
\text { Statistic }\end{array}$ & $\begin{array}{c}0.05 \\
\text { Critical } \\
\text { Value }\end{array}$ & Prob.** \\
\hline None * & 0.376610 & 70.93255 & 69.81889 & 0.0407 \\
\hline At most 1 & 0.276120 & 40.21469 & 47.85613 & 0.2149 \\
\hline At most 2 & 0.157494 & 19.21129 & 29.79707 & 0.4778 \\
\hline At most 3 & 0.114904 & 8.071907 & 15.49471 & 0.4578 \\
\hline At most 4 & 0.002122 & 0.138096 & 3.841466 & 0.7102 \\
\hline \multicolumn{5}{|l|}{ Trace test indicates 1 cointegratingeqn(s) at the 0.05 level } \\
\hline * denotes rejection of the hypothesis at the 0.05 level \\
\hline **MacKinnon -Haug -Michelis (1999) p -values \\
\hline
\end{tabular}

The null hypothesis of "there is no co-integration among the variables" is rejected as the value of Trace Statistic is higher than Critical Value (e.g. 70.93255>69.81889) and also the corresponding probability value of the comparison is less than 5 percent $(\mathrm{p}=$ $0.0407 / \mathrm{p}<5 \%$ ). Accordingly, the alternative hypothesis of "there is co-integration/cointegrating equation among the variables" is confirmed under the fulfillment of criteria such as the Critical Value should be less than the value of Trace Statistic and the value of probability of the corresponding comparison should be less than 5 percent.

As per the results of the Johansen Co-integration Trace Test, one maximum long run equilibrium co-integrating equation can be estimated to find out the value of long run coefficients of the relevant variables which are affecting the imports of Sri Lanka. 
Table 04: Co-integrating Coefficients

\begin{tabular}{|c|c|c|c|c|}
\hline \multicolumn{6}{|l|}{ Co-integrating coefficients } & \multicolumn{4}{c|}{ (standard error in parentheses) } \\
\hline LOG(IMP) & LOG(INR) & LOG(JAY) & LOG(STP) & LOG(USD) \\
\hline 1.000000 & 2.106717 & 6.069972 & 3.531096 & -13.43250 \\
\hline & $(0.72794)$ & $(1.12120)$ & $(1.54146)$ & $(2.52858)$ \\
\hline
\end{tabular}

Table 04 exposes all the values of long run equilibrium coefficients. The variables such as Indian Rupees, Japanese Yen, Pound Sterling, and US Dollar are estimated at 2.106717, 6.069972, 3.531096, and (-13.43250). Indian Rupees, Japanese Yen, and Pound Sterling are positively connected with the imports of Sri Lanka in the long run equilibrium. But only US Dollar is inversely connected with the imports of Sri Lanka in the long run equilibrium. In the long run, the most influencing factor which is affecting the imports of Sri Lanka is the currency of US Dollar along with the negative relationship. The most influencing variable on the imports of Sri Lanka is the currency of Japanese Yen along with the positive relationship with the imports of Sri Lanka. Because of the presence of long run co-integrating equilibrium equation, Vector Error Correction model can be developed further.

\section{Test of Structural Break}

In this test, the structural break in the trend of time series data from $1950-2017$ is found in year 2009. Table 05 shows results of Chow Breakpoint Test. The null hypothesis of "there is no structural break in the data set of time series from 1950 2017 " is rejected. As a result, the alternative hypothesis of "there is structure break in the data set of time series form 1950 - 2017' is confirmed as the Chow Breakpoint Test is significant less than 5 percent significant level $(p=0.0002)$. The structural break found in 2009 is ensured by this Chow Breakpoint Test.

\section{Table 05: Results of Chow Breakpoint Test}

\begin{tabular}{|l|l|l|l|}
\hline F-statistic & 5.678318 & Prob. F(5,58) & 0.0002 \\
\hline Log likelihood ratio & 27.09442 & Prob. Chi -Square(5) & 0.0001 \\
\hline Wald Statistic & 28.39159 & Prob. Chi -Square(5) & 0.0000 \\
\hline
\end{tabular}

Table 06 shows the results of the Chow Breakpoint Test. The multiple regression model originally used earlier in this study is currently converted to the multiple regression model by adding the dummy variable such as DU. The dummy variable represents the structural break in the time series data from $1950-2017$. The structure 
break found in year 2009 is breakpoint before which the data set is void by the value of zero. After the breakpoint (i.e. after 2009), the data set becomes valid by the value of one.

Table 06: Results after the Chow Breakpoint Test

\begin{tabular}{|c|c|c|c|c|}
\hline Variable & Coefficient & Std. Error & t-Statistic & Prob. \\
\hline $\mathrm{C}$ & 3.982234 & 0.916536 & 4.344876 & 0.0001 \\
\hline LOG(INR) & 0.012901 & 0.106983 & 0.120590 & 0.9044 \\
\hline LOG(JAY) & 0.009455 & 0.136680 & 0.069175 & 0.9451 \\
\hline LOG(STP) & 0.273776 & 0.175349 & 1.561316 & 0.1235 \\
\hline LOG(USD) & 0.805158 & 0.288786 & 2.788077 & 0.0070 \\
\hline DU & 0.468065 & 0.079767 & 5.867908 & 0.0000 \\
\hline R-squared & 0.986650 & \multicolumn{2}{|c|}{ Mean dependent var } & 7.525980 \\
\hline Adjusted R -squared & 0.985573 & \multicolumn{2}{|c|}{ S.D. dependent var } & 1.457356 \\
\hline S.E. of regression & 0.175044 & \multicolumn{2}{|c|}{ Akaike info criterion } & -0.563464 \\
\hline Sum squared resid & 1.899700 & \multicolumn{2}{|c|}{ Schwarz criterion } & -0.367625 \\
\hline Log likelihood & 25.15777 & \multicolumn{2}{|c|}{ Hannan -Quinn criter. } & -0.485866 \\
\hline F-statistic & 916.4433 & \multirow{2}{*}{\multicolumn{2}{|c|}{ Durbin -Watson stat }} & \multirow{2}{*}{0.889983} \\
\hline Prob(F -statistic) & 0.000000 & & & \\
\hline
\end{tabular}

In accordance to Table 06, the exchange rates of Indian Rupee and Japanese Yen are positively connected with the imports after the nature of adding the dummy variable (DU). Adding this dummy variable to this model is significant as the value of probability is less than five percent $(p=0.0000)$. Comparatively, those two variables are inversely connected with the imports earlier and presently both of them are directly connected with the imports.

\section{The new estimated regression model is as follows:}

$$
\ln \mathrm{IMP}=3.98+0.01 \ln \mathrm{INR}+0.009 \ln \mathrm{JAY}+0.27 \ln \mathrm{STP}+0.8 . \ln \mathrm{USD}+0.46 \mathrm{DU} \ldots . .(5)
$$

In accordance with the above equation (5), the dummy variable is positively connected with the imports. The value of coefficient of the dummy variable is 0.46 . As such, the total magnitude of the positive changes in the imports after year 2009 is 0.46 . Before the structural break (before year 2009), the total magnitude of the positive changes in the imports is subtracted by the value of 0.46 .

\section{Findings and Conclusion}

According to the results of the multiple regression model, the currencies such as Indian Rupees and Japanese Yen are inversely associated with the imports. The 
independent variables such as Pound Sterling of United Kingdom and Dollar of United States of America are positively connected with the Imports of Sri Lanka. The increase of one percent in Indian Rupees leads to decrease in imports of Sri Lanka by 0.10 percent. The increase of one percent in Japanese Yen causes to decrease the imports of Sri Lanka by 0.16 percent whereas the increase of one percent in Pound Sterling makes the imports of Sri Lanka to be also increased by 0.3 percent. The increase of one percent in US Dollar results in the increase of 1.12 percent in imports.

According to the Granger Causality Test, one way causal relationship is found between the currencies such as Indian Rupees, Japanese Yen, Pound Sterling, and US Dollar and the imports of Sri Lanka. As per the results of the Johansen Co-integration Trace Test, one maximum long run equilibrium co-integrating equation can be estimated to find out the value of long run coefficients of the relevant variables which are affecting the imports of Sri Lanka. The results of Johansen Co-integration Test vividly ensure the long run equilibrium relationship of the variables and the movement of all the variables together in the long run equilibrium.

On the basis of the findings of this study, it can be concluded that the considerable relationship is found between the imports of Sri Lanka and the dynamic changes in the values of currencies such as Indian Rupees, Japanese Yen, Pound Sterling, and US Dollar in Sri Lankan context over the past 65 years. The most influencing factor affecting the value of imports is the changes in the value of the currency of US Dollar along with the positive relationship. The changes in the currency values of US Dollar are found as the significant impacts on the imports of Sri Lanka. Further, it is concluded that, in the real scenario or the theoretical points of view, the value of foreign currency is negatively connected with the domestic imports as the purchasing power of domestic currency decreases. In this study, a Paradox of Positive Relationship between the currency values of Pound Sterling and US Dollar and the imports of Sri Lanka is found.

There is a structural break found in the time series data used in this study. This structural breakpoint is identified in year 2009 which is the year of cease-fire in Sri Lanka. After this year, a positive effect of change in the imports is estimated at 0.4.

\section{Recommendation}

On the basis of the findings and conclusions of this study, it is highly recommended that the respective policy makers of economics, the politicians, the stakeholders, and the government of Sri Lanka should be seriously considering the findings of this study. 
Accordingly, the value of imports can be lowered by the nature of appreciation of the currencies such as Indian Rupees and Japanese Yen in the floating exchange rate system and currency overvaluation in the fixed exchange rate system. By contrast, the value of imports can be lowered by the nature of depreciation of the currencies such as Pound Sterling and US Dollar in the floating and fixed exchange rates system respectively. This sort of Paradox is recommended to be named as Import Paradox of Pound-Dollar and also can be taught and added in the syllabus of International Economics.

\section{Contribution and Implication}

The value of import is one of the instrumental components in the trade balance of Balance of Payment of Sri Lanka. The trade balance in the Balance of Payment of Sri Lanka can be affected by the fluctuations in the exchange rate values of the currencies of the respective countries with Sri Lanka. As such, the international trade of Sri Lanka is affected by these fluctuations. The students who are learning International Trade and Exchange rate policy in the International Economics subject can link these two phenomena by using the results of this study applicably and practicably.

\section{Direction for the Future Research}

The value of import is the dependent variable of the multiple regression model used in this study. The value export can also be used as the dependent variable of the model in the future research. Only five independent variables are used in the multiple regression model used in this study. But there are a number of the different currencies exclusive to the respective countries all over the world. The value of the exchange rates of those currencies can be used in this study as the independent variables. On other hand, the value of exchange rates of the countries can also be used as dependent variables and thereby each of the exchange rates can be used as the dependent variables. As such, there are a number of simple and multiple regression models can be constructed on the basis of the respective objectives of the studies. Accordingly, the value of import or export can otherwise be used as the independent variables of the models used in the future studies. 


\section{References}

Ali Kemal, M, and Usman Qadir. (2005). Real Exchange Rate, Exports, and Imports Movements: A Trivariate Analysis. The Pakistan Development Review $44: 2$ (Summer 2005). pp. 177- 195. Available at: http://www.pide.org.pk/ pdf/ PDR/205/Volume2/177-195.

Cathy L, Jabara. (2009). How Do Exchange Rates Affect Import Prices? Recent Economic Literature and Data Analysis. Office of Industries Working Paper. US. International Trade Commission, Washington, DC 20436 USA. Available at: https://www.usitc.gov/publications/332/ID/21.

Faheem-ul-Hussain Dehraj, Irfan Ali, Muhammad Asif Channa. (2017). The Impact of Exchange Rate Fluctuation on Imports and Exports of Pakistan: TimeSeries Analysis From 1985-2015. International Journal of Management Sciences and Business Research. Jan-2017 ISSN (2226-8235) Vol-6, Issue 1. Available at: https://www.academia.edu /31644171/The_Impact_of Exchange_Rate_Fluctuation_on_Imports.

Hassana, A.B, and Nufile, A.A.M. (2016). Impact of Exchange Rate System on Imports and Exports: Special Reference with Sri Lanka after 1977. Research and Publications, 6th International Symposium, South Eastern University of Sri Lanka. Available at: http://www.seu.ac.lk/ researchandpublications /symposium/6th/IntSym\%202016\%20proceeding\%20final\%202\%20(1)\% 20-\%20Page \%2059-64.

IonelBostan, Carmen Toderascu (Sandu), and Bogdan-NarcisFirtescu.(2018). Exchange Rate Effects on International Commercial Trade Competitiveness. Journal of Risk and Financial Management, MDPI, Available at: https://res.mdpi.com/jrfm/jrfm/11 ...jrfm/11/00019.

Khaled, A. (2016). How Exchange Rate Influence a Country's Import and Export. International Journal of Scientific \& Engineering Research, Volume 7, Issue 5, May-2016. ISSN 2229-5518. Available at: https://www.ijser.org/ researchpaper/ How/ Exchange/ Rate/ Influence/ a/ Countrys/ Import/ and/ Export.

Mary Amiti, Oleg Itskhoki, and JozefKonings. (2014). Importers, Exporters, and Exchange Rate Disconnect. Published in the American Economic Review, July 2014, 104(7): 1942-78. Available at: https://www.princeton.edu/ itskhoki/papers/ImportsAndPass Through. 